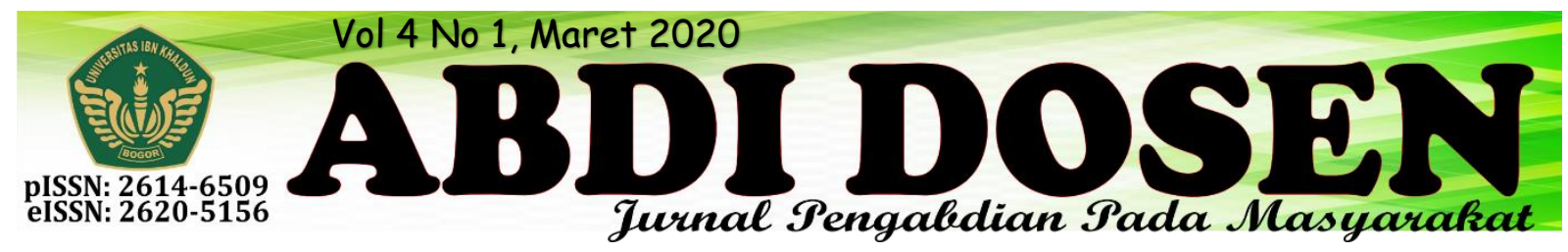

\title{
MENGOPTIMALKAN POTENSI WARGA DESA BABAKAN SADENG DALAM UPAYA MENINGKATKAN LINGKUNGAN SEHAT SDM UNGGUL MENUJU DESA YANG CERDAS, SEHAT DAN MANDIRI
}

\author{
Ibrahim Fajri $^{1}$, Sri Nurul Milla ${ }^{2}$, Muhammad Pajriansyah ${ }^{3}$ \\ ibrahim@uika-bogor.ac.id ${ }^{1}$ \\ $\underline{\text { sn.milla@fai.uika-bogor.ac.id }}^{2}$ \\ mpajri140@gmail.com ${ }^{3}$ \\ Fakultas Hukum¹, Fakultas Agama Islam², Mahasiswa KKN Kelompok 29\&30 Tahun $2019^{3}$.
}

\begin{abstract}
ABSTRAK
Salah satu permasalahan yang ada dimasyarakat Desa Babakan Sadeng, Kecamatan Leuwisadeng, Kabupaten Bogor adalah banyaknya sampah disekitar lingkungan warga. Sampah sampah ini berupa sampah organik maupun nonorganic. Dengan kuantitas sampah yang cukup banyak menjadikan adanya penumpukan sampah dilingkungan sekitar warga. Program KKN kelompok 29 dan 30 Universitas Ibn Khaldun Bogor yang di tempatkan di Desa Babakan sadeng ini akan memfokuskan pada pemberdayaan masyarakat dalam pemanfaatan sampah. Program ini bertujuan memberdayakan masyarakat Desa Babakan Sadeng, dalam program pemanfaatan sampah sehingga sampah yang ada di lingkungan warga bisa diubah menjadi barang yang lebih menguntungkan dan tentu saja mengurangi volume sampah itu sendiri. Metode pelaksanaan program KKN di desa babakan sadeng ini meliputi: pendidikan kepada masyarakat, penyuluhan mengenai sampah dan praktek langsung. Dampak dari kegiatan KKN ini adalah: 1) tercipta kesadaran masyarakat tentang pentingnya PHBS, 2) peningkatan pengetahuan masyarakat dalam mengolah sampah organik dan nonorganik, 3) masyarakat terampil membuat karya kreatif dari barang bekas, dan sampah plastic yang bisa di daur ulang.
\end{abstract}

Kata kunci: pemberdayaan masyarakat, recycle, Babakan Sadeng Bersih Sampah 2019

\section{PENDAHULUAN}

Desa Babakan Sadeng adalah salah satu dari 8 (delapan) desa yang ada di Kecamatan Leuwisadeng Kabupaten Bogor. Desa Babakan Sadeng berada pada $21 \mathrm{Km}$ dari Kecamatan Leuwisadeng. Jumlah penduduk keseluruhan Desa Babakan Sadeng adalah 8.812 jiwa. Desa Babakan Sadeng memiliki luas wilayah 2443,25 ha. Dengan batas wilayah Sebelah Utara Desa Sadeng, Sebelah Selatan Desa Wangunjaya Sebelah Timur Desa Sadeng Kolot, Sebelah Barat Desa Sukaluyu Kalong Liud arah barat daya. Desa Babakan
Sadeng menpunyai banyak sumber daya alam diantaranya Tanah Kas Desa dengan luas $2.500 \mathrm{~m}^{2}$, Lahan Perkarangan dengan luas 57,9 Ha, Persawahan dengan luas 115 Ha, Tanah Perkebunan dengan luas 69,3 Ha , Tanah Perkantoran dengan luas $700 \mathrm{~m}^{2}$, Sumber Mata air dengan jumlah 5 titik, Hutan Rakyat dengan luas $1 \mathrm{Ha}$, Bangunan Sekolah yang berjumlah 13 unit, Sungai/ Selokan dengan jumlah 5 aliran, tanah kuburan umum dengan jumlah 3 titik. terdapat total $8 \mathrm{RW}$ dan $38 \mathrm{RT}$ yang ada di wilayah Desa Babakan Sadeng tersebut. 
Dengan

teridentifikasinya permasalahan seperti tersebut diatas, sangat penting untuk diadakan program pendidikan dan pengelolaan sampah bagi masyarakat Desa babakan sadeng. Selain untuk mengurangi volume sampah yang ada, program pemberdayaan pengelolaan sampah akan mendukung program pemerintah desa babakan sadeng Bersih Sampah 2019.

Peran serta masyarakat dalam pengelolahan lingkungan merupakan kesediaan masyarakat untuk membantu berhasilnya program pengembangan pengelolaan lingkungan. Ada beberapa permasalahan yang terdapat di Desa Babakan Sadeng, diantaranya adalah Kurangnya perhatian orangtua terhadap pendidikan anaknya, Kurangnya memanfaatkan peluang untuk mengelola sampah, Kurangnya kesadaran masyarakat akan pentingnya kebersihan lingkungan, sehingga menjadi penyebab utama timbulnya permasalahan lingkungan.

\section{Solusi Yang di Tawarkan}

Setelah memahami beberapa permasalahan yang terjadi di Desa Babakan Sadeng, maka kami menawarkan beberapa solusi yang terbaik untuk membantu memajukan Desa Babakan Sadeng, solusisolusi tersebut diantaranya :

1. Adanya program bimbingan belajar kepada anak-anak dalam membantu menyelesaikan pekerjaan rumah dari sekolah dan memberikan pengetahuan tambahan kepada anak-anak berupa les bahasa inggris dan komputer.

2. Adanya program membantu memberikan pengajaran kepada anakanak sekolah dasar di SDN Babakan Sadeng 01 dan MI Al - Barkah.

3. Adanya program learning motivation dan menonton film bersama tentang belajar dan pentingnya kebersihan kepada anak-anak sekolah dasar di SDN Babakan Sadeng 01 dan MI Al - Barkah.

Secara geografis, dari segi akses masuk, Desa babakan sadeng sudah memiliki akses jalan yang bagus dan memadai. Dengan kondisi yang seperti ini, sangat mudah untuk warga desa yang berniat pergi ke pusat desa.

Sementara itu, keadaan tanah di Desa Bababkan Sadeng sangat subur tetapi jumlah air kuranag memadai bagi kebutuhan warga. Dengan kondisi geografis yang seperti ini, mayoritas masyarakat Desa babakan sadeng bermata pencaharian sebagai petani yang menanam tanaman pangan dan juga menanam serta mengolah tanaman perkebunan.

Meskipun secara kondisi alam warga Desa babakan sadeng tidak memiliki banyak kendala, namun bukan berarti tidak ada permasalahan yang ada di Desa babakan sadeng. Dari hasil analisis situasi yang dilakukan, ditemukan beberapa permasalahan di Desa babakan sadeng, antara lain:

1 banyaknya sampah di sekitar lingkungan, 2) kurangnya kesadaran masyarakat tentang pentingnya PHBS,

2 kurangnya pengetahuan masyarakat dalam memilah sampah organik dan anorgnik

3 kurangya keterampilan masyarakat dalam memanfaatkan sampah.

4. Adanya program bimbingan mengaji kepada anak-anak dalam membantu pembacaan huruf Hijaiyah dan pengetahuan agama lainnya sepeti cara berwudhu dan lain-lain.

5. Adanya program membantu pelaksaan kegiatan Idul Adha di Lingkungan Kp. Sadeng Pasar Desa Babakan Sadeng.

6. Adanya penyuluhan sikat gigi dan cuci tangan kepada anak-anak sekolah dasar 
din SDN Babakan Sadeng 01 dan MI $\mathrm{Al}$ - Barkah

7. Adanya program cek kesehatan gratis terhadap warga dan staff desa Babakan Sadeng.

8. Adanya program senam sehat yang dilakukan di lingkungan RW 003 Desa babakan Sadeng.

9. Adanya program Jum'at bersih yang dilakukan di lingkungan RW 003 Desa Babakan sadeng.

10. Adanya program dalam pelaksanan HUT RI ke 74 di Kp. Sadeng Pasar RW 003 Desa Babakan Sadeng.

11. Adanya program penyuluhan tentang sampah dari aspek Pendidikan, Agama, Kesehatan, Hukum, Ekonomi, dan Teknik .

12. Adanya program pengadaan tong sampah di lingkungan Kp. Sadeng Pasar RW 003 Desa Babakan Sadeng.
13. Adanya program pengadaan 1000 pohon di lingkungan Kp. Sadeng Pasar RW 003 Desa Babakan Sadeng.

14. Memberikan inovasi baru serta pelatihan terhadap warga Kp. Sadeng Pasar RW 003 Desa Babakan Sadeng seperti pembuatan Packaging bunga kering dalam bentuk bucket untuk meningkatkan harga jual.

15. Memberikan inovasi baru serta pelatihan terhadap warga Kp. Sadeng Pasar RW 003 Desa babakan Sadeng dengan bentuk daur ulang sampah dari kantong kresek menjadi kerajinan dalam bentuk hiasan bunga.

16. Adanya program pemberian pengetahuan terhadap masyarakat tentang e-commererce di Desa Babakan Sadeng.

\section{METODE PELAKSANAAN}

Tahapan pelaksanaan untuk kegiatan program kerja sebagaimana terlihat pada bagian sebagai berikut :

\begin{tabular}{|c|c|c|c|c|c|c|c|c|c|c|c|c|c|c|c|c|c|c|c|c|c|c|c|c|c|c|c|c|}
\hline \multirow{2}{*}{ No } & \multirow{2}{*}{ KEGIATAN } & \multicolumn{24}{|c|}{ AGUSTUS } & \multicolumn{3}{|c|}{ SEPTEMBER } \\
\hline & & 6 & 7 & 8 & $9[1$ & $10[1$ & $1[1$ & $\begin{array}{lll}2 & 13 \\
3\end{array}$ & \begin{tabular}{l|l}
3 & 14 \\
\end{tabular} & 45 & 516 & \begin{tabular}{l|l}
6 & 17
\end{tabular} & 18 & 19 & 202 & \begin{tabular}{|l|l|l}
21 & 22 \\
$r$
\end{tabular} & 2223 & \begin{tabular}{l|l}
23 & 24 \\
\end{tabular} & $4 \mid 425$ & $5 \longdiv { 2 6 }$ & 627 & 728 & 2930 & $30 \mid 31$ & \begin{tabular}{l|l}
1 & 1 \\
1
\end{tabular} & \begin{tabular}{l|l|l|}
1 & 2 \\
\end{tabular} & \begin{tabular}{|l|l|}
3 & 4 \\
\end{tabular} & $\begin{array}{ll}4 & 5 \\
\end{array}$ \\
\hline 1 & Pelepasan di Kampus UIKA & & & & & & & & & & & & & & & & & & T & & 7 & 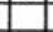 & & & & $\square$ & & \\
\hline 2 & Serah Terima di Kecamatan & & & & & & & & & & & & & & & & & & & & & & & & & & & \\
\hline 3 & Silaturahmi dengan : & & & & & & & & & & & & & & & & & & & & & & & & & & & \\
\hline & RW 003 & & & & & & & & & & & & & & & & & & & & & & & & & & & \\
\hline & RT 001-RT 006 & & & & & & & & & & & & & & & & & & & & & & & & & & & \\
\hline 4 & Silaturahmi dengan : & & & & & & & & & & & & & & & & & & & & & & & & & & & \\
\hline & Ketua Pemuda & & & & & & & & & & & & & & & & & & & & & & & & & & & \\
\hline & Ketua Karang Taruna & & & & & & & & & & & & & & & & & & & & & & & & & & & \\
\hline & Ustad Ending \& Ustad Tatang & & & & & & & & & & & & & & & & & & & & & & & & & & & \\
\hline 5 & Sosialisasi Proker dengan : & & & & & & & & & & & & & & & & & & & & & - & & & & & & \\
\hline & Kepala Desa & & & & & & & & & & & & & & & & & & & & & & & & & & & \\
\hline & Ketua RW & & & & & & & & & & & & & & & & & & & & & & & & & & & \\
\hline & Ketua RT 001 - RT 006 & & & & & & & & & & & & & & & & & & & & & & & & & & & \\
\hline 6 & Keliling Desa Babakan Sadeng & & & & & & & & & & & & & & & & & & & & & & & & & & & \\
\hline 7 & Idul Adha & & & & & & & & & & & & & & & & & & & & & & & & & & & \\
\hline 8 & Mengajar di : & & & & & & & & & & & & & & & & & & & & & & & & & & & \\
\hline & SDN Babakan Sadeng 01 & & & & & & & & & & & & & & & & & & & & & & & & & & & \\
\hline & MI Al-Barkah & & & & & & & & & & & & & & & & & & & & & 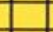 & & & & & 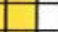 & \\
\hline & TPA Raudhatussa'adah & & & & & & & & & & & & & & & & & & & & & & & & & & & \\
\hline 9 & 17 Agustus 2019 & & & & & & & & & & & & & & & & & & & & & & & & & & & \\
\hline 10 & Penyuluhan Tentang Sampah & & & & & & & & & & & & & & & & & & & & & & & & & & & \\
\hline 11 & penyuluhan E-Commerce & & & & & & & & & & & & & & & & & & & & & & & & & & & \\
\hline 12 & PHBS Cuci Tangan \& Sikat Gigi & & & & & & & & & & & & & & & & & & & & & & & & & & & \\
\hline 13 & Jum'at Bersih & & & & & & & & & & & & & & & & & & & & & & & & & & & \\
\hline 14 & Senam Sehat & & & & & & & & & & & & & & & & & & & & & & & & & & & \\
\hline 15 & Learning Motivation \& Nonton Film & & & & & & & & & & & & & & & & & & & & & & & & & & & \\
\hline 16 & Cek Kesehatan Gratis & & & & & & & & & & & & & & & & & & & & & - & & & & 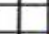 & & \\
\hline 17 & Pelatihan Packaging & & & & & & & & & & & & & & & & & & & & & & & & & & & \\
\hline 18 & Pelatihan Daur Ulang Sampah & & & & & & & & & & & & & & & & & & & & & & & & & & & \\
\hline 19 & Pembagian Tong Sampah & & & & & & & & & & & & & & & & & & & & & & & & & & & \\
\hline 20 & Pembagian 1000 Pohon & & & & & & & & & & & & & & & & & & & & & & & & & & & \\
\hline 21 & Penutupan di Kecamatan \& Desa & & & & & & & & & & & & & & & & & & & & & & & & & & & \\
\hline
\end{tabular}




\section{Metode Pendekatan}

Ada beberapa pendekatan yang dilakukan oleh kami demi kelancaran program kerja yang sudah kami bikin selama 1 bulan di Desa Babakan Sadeng, pendekatan tersebut diantaranya :

\section{Pendekatan Organisasi}

Organisasi meruakan hal yang paling penting keberadaannya di tengah-tengah masyarakat. Pendekatan organisasi kami anggap penting karena peran organisasi begitu besar, sehingga bisa mempermudah kami untuk melakukan pengenalan kami kepada warga Desa Babakan Sadeng.

2. Pendekatan Religius

Pendekatan religius adalah pendekatan yang kami lakukan dengan cara mengikuti kegiatan keagaaman yang dilaksanakan oleh masyarakat Desa Babakan Sadeng berupa bergabung mengikuti Majlis Ta'lim ibu-ibu maupun bapak-bapak.

3. Pendekatan Masyarakat

Pendekatan masyarakat adalah pendekatan yang kami lakukan dengan cara memahami kebiasaan masyarakat Desa Babakan Sadeng, sehingga bisa mempermudah kami untuk menjalankan program kerja kelompok kami.

4. Pendekatan Edukasi

Pendekatan edukasi adalah pendekatan yang sangat penting di Desa Babakan Sadeng, menginggat latar belakang masyarakat Desa Babakan Sadeng yang berbeda-beda. Maka dari itu pendekatan ini sangatlah kami perlukan untuk mempermudah pendekatan dan pengenalan program kerja kami kepada masyarakat selama di Desa Babakan Sadeng.

\section{Langkah Evaluasi}

Evaluasi yang kami lakukan terdiri dari :

1. Evaluasi proses yang terdiri dari kegiatan perencanaan, pelaksanaan dan monitoring kegiatan. Evaluasi proses akan dilakukan disetiap kegiatan yang akan dan telah kami lakukan.

2. Evaluasi hasil adalah evaluasi yang kami lakukan setelah keseluruhan program kerja telah selesai kami laksanakan. Evaluasi hasil yang dilakukan terdiri dari :

\section{Bidang Pendidikan}

Pelaksanaan kegiatan program kerja dari pendidikan yang dilaksanakan oleh mahasiswa KKN kelompok 29 \& 30 mendapatkan respon dan dukungan yang baik dari masyarakat Desa Babakan Sadeng, dimana dengan adanya program kerja dari pendidikan sangat membantu tenaga pengajar di Desa Babakan Sadeng khususnya di SDN Babakan Sadeng 01 dan MI Al - Barkah, selain itu para orangtua juga merasa terbantukan dengan adanya mahasiswa KKN kelompok 29 \& 30 sehingga bisa menambah pengetahuan anak mereka dengan adanya ekskul dan bimbel yang diadakan oleh bidang pendidikan.

\section{Bidang Keagamaan}

Pelaksanaan kegiatan program kerja dari keagamaan yang dilaksanakan oleh mahasiswa KKN kelompok 29 \& 30 mendapatkan respon dan dukungan yang baik dari masyarakat Desa Babakan Sadeng, dimana dengan adanya program kerja dari keagamaan sangat membantu tenaga pengajar di Desa Babakan Sadeng khususnya di TPA Raudhatussa'adah, serta dengan banyaknya ajakan dari masyarakat terhadap mahasiswa KKN kelompok 29 \& 30 untuk mengikuti kegiatan keagaaman yang dilaksanakan oleh masyarakat Desa Babakan Sadeng. 


\section{Bidang Kesehatan}

Pelaksanaan kegiatan program kerja dari kesehatan yang dilaksanakan oleh mahasiswa KKN kelompok 29 \& 30 mendapatkan respon dan dukungan yang baik dari masyarakat Desa Babakan Sadeng, dimana dengan adanya program kerja kesehatan sangat membantu para pelajar di SDN Babakan Sadeng 01 dan MI Al - Barkah untuk bisa menambah wawasan penting akan pentingnya cuci tangan dan sikat gigi, serta dengan adanya cek kesehatan sangat membantu masyarakat untuk mengubah pola hidupnya menjadi lebih baik lagi.

4. Bidang Ekonomi

Pelaksanaan kegiatan program kerja dari ekonomi yang dilaksanakan oleh mahasiswa KKN kelompok 29 \& 30 mendapatkan respon dan dukungan yang baik dari masyarakat Desa Babakan Sadeng, dimana dengan adanya program kerja ekonomi dapat membantu meningkatkan harga jual kerajinan bunga kering yang dirintis oleh masyarakat Desa Babakan Sadeng di RT 001 dengan adanya program kerja packaging, serta mengubah pola pikir masyarakat Desa Babakan Sadeng terhadap sampah bahwa sampah

\section{REALISASI PROGRAM}

Berikut adalah capaian program kerja yang telah kami laksanakan :

\section{Bidang Pendidikan}

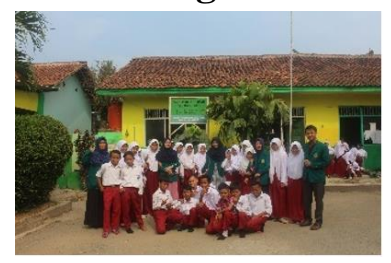

a) Pengajaran

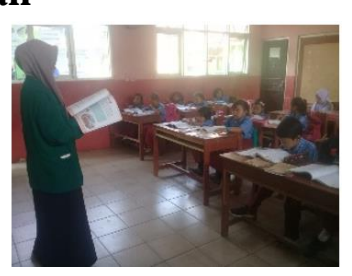

bila di olah dengan benar bisa menghasilkan rupiah.

5. Bidang Hukum

Pelaksanaan kegiatan program kerja dari hukum yang dilaksanakan oleh mahasiswa KKN kelompok 29 \& 30 mendapatkan respon dan dukungan yang baik dari masyarakat Desa Babakan Sadeng, dimana dengan adanya program kerja hukum dapat meningkatkan kesadaran masyarakat akan pentingnya menjaga kebersihan lingkungan di Desa Babakan Sadeng serta menambah wawasan masyarakat terkait Peraturan Daerah Kabupaten Bogor No. 2 Tahun 2014 Tentang Pengelolaan Sampah

6. Bidang Teknik

Pelaksanaan kegiatan program kerja dari teknik yang dilaksanakan oleh mahasiswa KKN kelompok 29 \& 30 mendapatkan respon dan dukungan yang baik dari masyarakat Desa Babakan Sadeng, dimana dengan adanya program kerja teknik berupa amdal dan pengadaan tong sampah dapat meningkatkan kesadaran masyarakat akan pentingnya menjaga kebersihan lingkungan di Desa Babakan Sadeng.
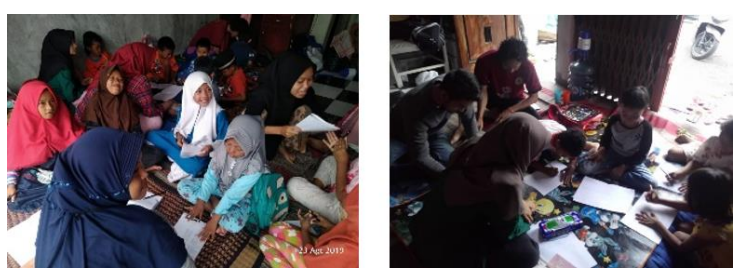

b) Bimbel

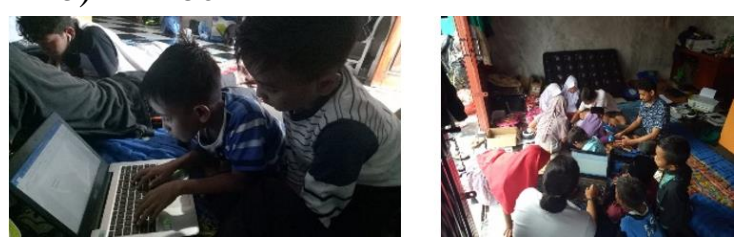

c) Ekskul Bahasa Inggris \& Komputer 

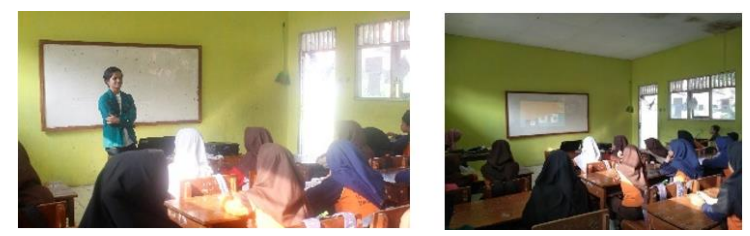

d) Learning Motivation \& Nonton Film

e) Penyuluhan Sampah

\section{Bidang Keagamaan}

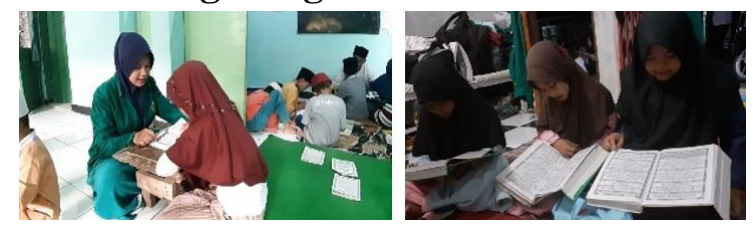

a) Pengajaran Ngaji

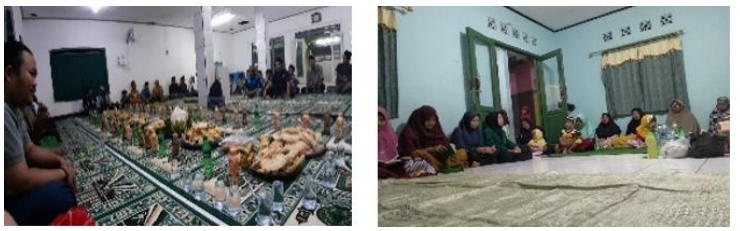

b) Pengajian \& Pembacaan Surat Yasin
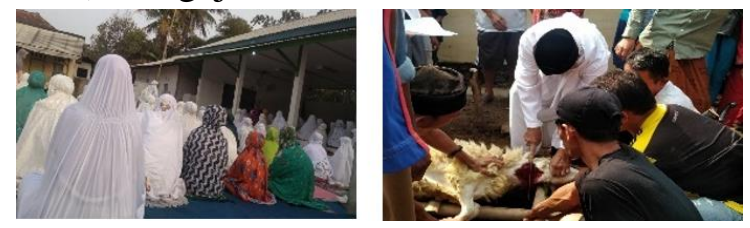

c) Idul Adha

d) Penyuluhan Sampah

\section{Bidang Kesehatan}
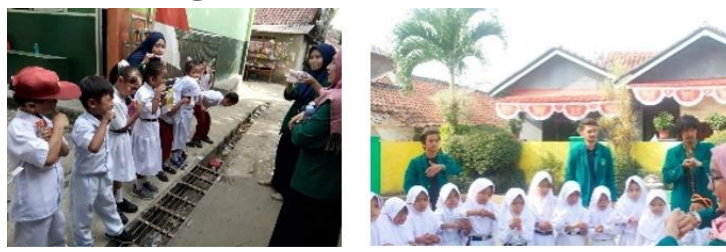

a) PHBS Cuci Tangan \& Sikat Gigi
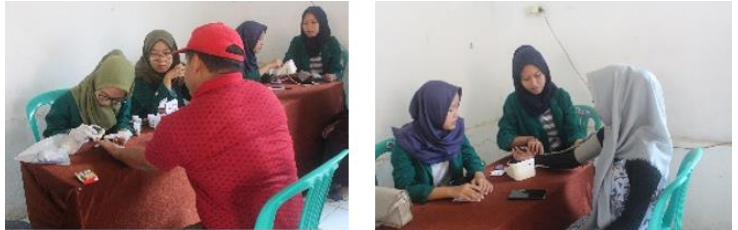

b) Cek Kesehatan Gratis
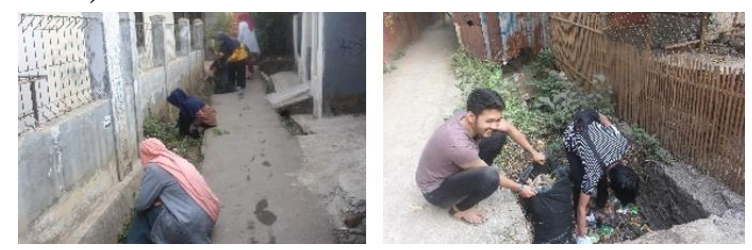

c) Jum'at Bersih d) Senam Sehat

e) Penyuluhan Sampah

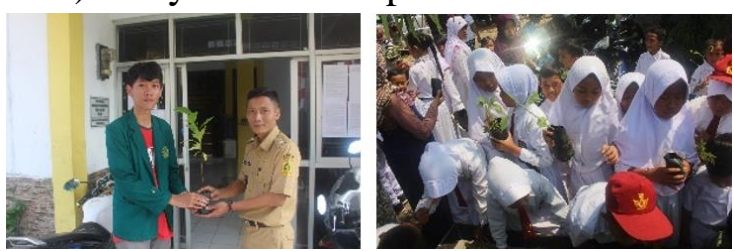

f) Pembagian 1000 Pohon

\section{Bidang Ekonomi}

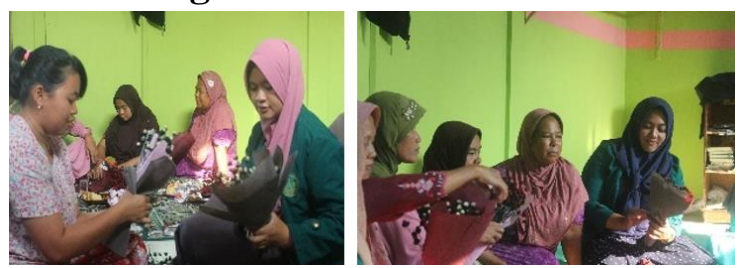

a) Packaging

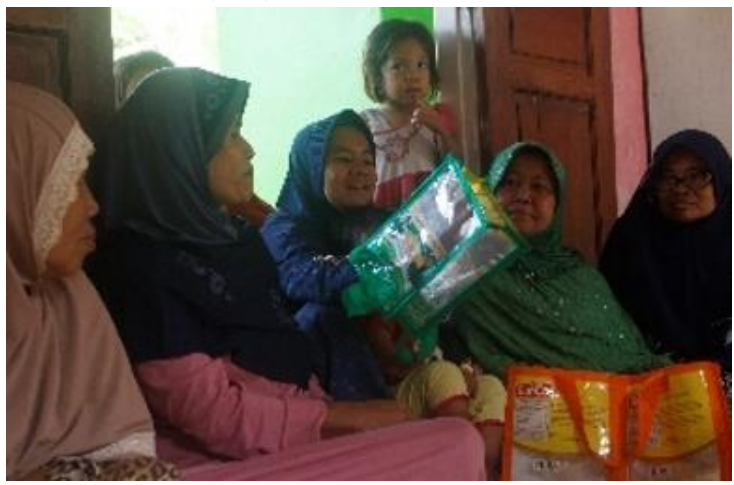

b) Pengolahan Sampah Menjadi kerajinan

c) Penyuluhan Sampah

\section{Bidang Hukum}

a) Penyuluhan Sampah

\section{Bidang Teknik}

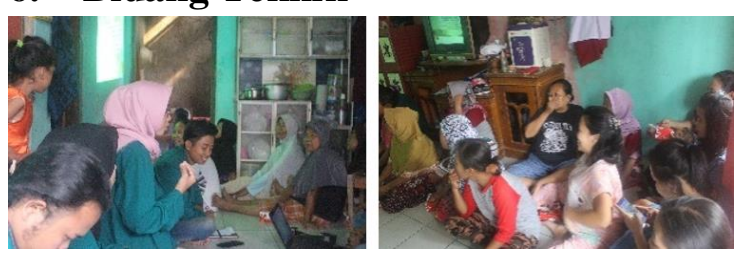

a) Penyuluhan Amdal

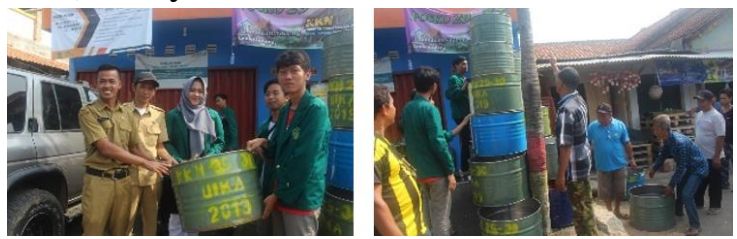

b) Pembagian Tong Sampah 


\section{KESIMPULAN}

Berdasarkan hasil pengamatan, kegiatan, serta pelaksanaan program kerja KKN Kelompok 29 \& 30 yang telah di rencanakan, disusun, dan dilaksanakan di Desa Babakan Sadeng. Maka kami dapat mengambil beberapa kesimpulan yaitu :

1. Kurangnya kepedulian masyarakat Desa Babakan Sadeng terhadap lingkungan sekitar, terlihat dengan banyaknya sampah yang dibuang sembarangan.

2. Keberhasilan KKN kelompok $29 \& 30$ tidak terlepas dari kerja sama antara mahasiswa dengan perangkat desa, tokoh masyarakat, seluruh lapisan masyarakat serta seluruh pihak yang sudah mendukung dan membantu terlaksananya program kerja $\mathrm{KKN}$ kelompok 29 \& 30 di Desa Babakan Sadeng.

3. Dengan adanya kehadiran mahasiswa KKN kelompok 29 \& 30 di Desa babakan Sadeng, masyarakat terbantu dengan bertambahnya informasi dan ilmu pengetahuan yang di peroleh dari mahasiswa KKN kelompok 29 \& 30.

4. Dengan adanya KKN di Desa Babakan Sadeng membuat kami mahasiswa KKN kelompk 29 \& 30 dapat memperoleh ilmu baru yang kami dapatkan dari masyarakat di Desa Babakan Sadeng.

Berdasarkan beberapa kesimpulan diatas, maka secara garis besar dapat dikatakan bahwa program kerja yang telah kami rencanakan telah berjalan dengan sukses dan lancar meskipun pada pelaksanaan program kerja tersebut terjadi beberapa kendala yang terjadi baik dari pihak mahasiswa maupun dari pihak masyarakat di Desa Babakan Sadeng. Namun kendala tersebut bisa kami atasi sehingga tidak mengganggu berjalannya program kerja tersebut.

\section{Dampak Bagi Masyarakat}

Dalam program-program kerja yang telah kami laksanakan memiliki dampak yang dapat diperoleh masyarakat Desa Babakan Sadeng antara lain :

\section{Bidang Pendidikan}

a) Pengajaran

Manfaat dari penyelenggaraan program pengajaran yang kami lakukan di SDN Babakan Sadeng 01 dan MI Al Barkah adalah selain dapat membantu tenaga pengajar di kedua sekolah tersebut dengan adanya kehadiran mahasiswa KKN kelompok 29 \& 30 juga dapat memotivasi para pelajar di kedua sekolah serta para pelajar bisa mendapatkan ilmu baru yang bisa didapatkan dari mahasiswa $\mathrm{KKN}$ kelompok $29 \& 30$.

b) Bimbel

Manfaat dari penyelenggaraan program bimbel yang kami lakukan di Posko adalah untuk menambah motivasi bagi anak-anak di Desa Babakan Sadeng, membantu anak-anak dalam menyelesaikan PR mereka, serta menambah waktu anakanak untuk belajar pelajaran yang belum mereka pahami.

c) Ekskul Bahasa Inggris \& Komputer

Manfaat dari penyelenggaraan program ekskul yang kami lakukan di Posko adalah untuk memberika tambahan waktu belajar anak-anak dalam pelajaran bahasa inggris dan komputer, membantu anak-anak supaya berani untuk menggunakan bahasa inggris, serta supaya anak-anak dapat memahami dan mengoperasikan komputer.

d) Learning Motivation \& Nonton Film

Manfaat dari penyelenggaraan program learning motivation dan nonton film di SDN Babakan Sadeng 01 dan MI Al - Barkah adalah supaya para pelajar di kedua sekolah tersebut dapat termotivasi 
dalam hal belajar sehingga mereka dapat mempunyai keinginan untuk melanjutkan pendidikan hingga kejenjang yang lebih tinggi dan dengan adanya program nonton film kami mengharapkan para pelajar dapat lebih peduli akan kebersihan lingkungan disekitar mereka.

e) Penyuluhan Sampah

Manfaat dari penyelenggaraan program penyuluhan sampah yang kami lakukan di lingkungan RW 003 Desa Babakan sadeng adalah supaya masyarakat dapat lebih sadar akan kebersihan lingkungan disekitar mereka serta supaya masyarakat dapat membedakan jenis-jenis sampah sehingga diharapkan setelah kegiatan KKN ini masyarakat dapat melakukan daur ulang sesuai dengan jenis sampah yang dihasilkan.

\section{Bidang Keagamaan}

\section{a) Pengajaran Ngaji}

Manfaat dari penyelenggaraan program pengajaran Ngaji yang kami lakukan di TPA Raudhatussa'adah adalah selain dapat membantu tenaga pengajar di TPA tersebut dengan adanya kehadiran mahasiswa KKN kelompok 29 \& 30 juga dapat memotivasi anak-anak yang tidak mengaji di TPA Raudhatussa'adah, hal ini terbukti dengan kehadiran anak-anak di Posko kami untuk mengaji.

b) Pengajian \& Pembacaan Surat Yasin

Manfaat dari penyelenggaraan program pengajian dan pembacaan surat yasin yang kami lakukan dilingkungan RW 003 Desa Babakan sadeng adalah untuk mendekatkan mahasiswa KKN kelompok 29 \& 30 dengan masyarakat dilingkungan RW 003 Desa Babakan Sadengserta untuk menjalin silaturahmi antara mahasiswa dengan masyarakat serta para tokoh masyarakat di lingkungan RW 003 Desa Babakan sadeng. c) Idul Adha

Manfaat dari penyelenggaraan program idul adha yang kami lakukan dilingkungan RW 003 Desa Babakan Sadeng adalah untuk mendekatkan mahasiswa KKN kelompok 29 \& 30 dengan masyarakat dilingkungan RW 003 Desa Babakan Sadeng serta untuk membantu masyarakatdilingkungan RW 003 Desa Babakan Sadeng.

d) Penyuluhan Sampah

Manfaat dari penyelenggaraan program penyuluhan sampah yang kami lakukan di lingkungan RW 003 Desa Babakan sadeng adalah supaya masyarakat dapat lebih sadar akan kebersihan lingkungan disekitar mereka dari segi agama.

\section{Bidang Kesehatan}

\section{a) PHBS Cuci Tangan \& Sikat Gigi}

Manfaat dari penyelenggaraan program PHBS cuci tangan dan sikat gigi yang kami lakukan di SDN Babakan Sadeng 01 dan MI Al - Barkah adalah untuk memberikan informasi mengenai pentingnya cuci tangan dan sikat gigi kepada para pelajar di kedua sekolah tersebut serta untuk membiasakan para pelajar untuk melakukan cuci tangan dan sikat gigi dalam kehidupan sehari-hari.

\section{b) Cek Kesehatan Gratis}

Manfaat dari penyelenggaraan program cek kesehatan gratis yang kami lakukan di Balai Desa Babakan Sadeng adalah untuk memberikan pemeriksaan gratis kepada masyarakat dilingkungan RW 003 Desa Babakan Sadeng berupa cek berat badan, tinggi badan, tekanan darah, kolesterol, asam urat, dan gula darah.

c) Jum'at Bersih

Manfaat dari penyelenggaraan program jum'at bersih yang kami lakukan dilingkungan RW 003 Desa Babakan Sadeng adalah untuk membuat lingkungan 
RW 003 Desa Babakan Sadeng menjadi bersih serta untuk mengajak masyarakat untuk lebih mencintai kebersihan lingkungan RW 003 Desa Babakan Sadeng.

d) Senam Sehat

Manfaat dari penyelenggaraan program senam sehat yang kami lakukan dilingkungan RW 003 Desa Babakan Sadeng adalah untuk membuat masyarakat dilingkungan RW 003 Desa Babakan Sadeng menjadi lebih sehat dan bugar serta supaya dapat mengubah pola hidup masyarakat menjadi lebih sehat.

e) Penyuluhan Sampah

Manfaat dari penyelenggaraan program penyuluhan sampah yang kami lakukan di lingkungan RW 003 Desa Babakan Sadeng adalah supaya masyarakat dapat lebih sadar akan kebersihan lingkungan disekitar mereka dari segi kesehatan.

f) Pembagian 1000 Pohon

Manfaat dari penyelenggaraan program pembagian 1000 pohon yang kami lakukan di lingkungan RW 003 Desa Babakan Sadeng adalah untuk membuat wilayah di lingkungan RW 003 Desa Babakan sadeng menjadi lebih asri.

\section{Bidang Ekonomi}

a) Packaging

Manfaat dari penyelenggaraan program packaging yang kami lakukan di lingkungan RT 001 Desa Babakan Sadeng adalah untuk membantu pengrajin bunga keringdi lingkungan RT 001 Desa Babakan sadeng untuk meningkatkan harga jual dengan membuat packaging yang lebih menarik dari adanya pelatihan packaging dari mahasiswa KKN kelompok 29 \& 30.

b) Pengolahan Sampah Menjadi kerajinan

Manfaat dari penyelenggaraan program pengolahan sampah menjadi kerajinan yang kami lakukan di lingkungan RW 003 Desa Babakan sadeng adalah untuk memberikan informasi baru kepada masyarakat di lingkungan RW 003 Desa Babakan sadeng bahwa sampah bisa diolah kembali menjadi kerajinan yang memiliki nilai jual serta supaya masyarakatdi lingkungan RW 003 Desa Babakan sadeng bisa membuat kerajinan dengan adanya latihan langsung untuk membuat kerajinan tersebut.

c) Penyuluhan Sampah

Manfaat dari penyelenggaraan program penyuluhan sampah yang kami lakukan di lingkungan RW 003 Desa Babakan sadeng adalah supaya masyarakat dapat lebih sadar akan kebersihan lingkungan disekitar mereka dari segi .

\section{Bidang Hukum}

a) Penyuluhan Sampah

Manfaat dari penyelenggaraan program penyuluhan sampah yang kami lakukan di lingkungan RW 003 Desa Babakan sadeng adalah supaya masyarakat dapat lebih sadar akan kebersihan lingkungan disekitar mereka dari segi hukum.

\section{Bidang Teknik}

\section{a) Penyuluhan Amdal}

Manfaat dari penyelenggaraan program penyuluhan amdal yang kami lakukan di lingkungan RW 003 Desa Babakan sadeng adalah supaya masyarakat mengetahui dampak yang akan ditimbulkan dari kebiasaan buruk masyarakatberupa membuang sampah sembarangan di lingkungan RW 003 Desa Babakan sadeng sehingga kami mengharapkan kedepan masyarakat sudh tidak membuang sampah secara sembarangan lagi.

b) Pembagian Tong Sampah

Manfaat dari penyelenggaraan program pembagian tong sampah yang kami lakukan di lingkungan RW 003 Desa Babakan sadeng adalah supaya masyarakat mau untuk membuang sampah pada tempat 
yang sudah disediakan sehingga kebersihan di lingkungan RW 003 Desa Babakan sadeng dapat terjaga.

\section{REFERENSI}

Brigita, Gladys dan Benno Rahardyan. (2013). Analisa Pengelolaan Sampah Makanan di Kota Bandung. Institut Teknologi Bandung.

Panitia KKN UIKA Bogor. 2019. Petunjuk Pelaksanaan KKN Tematik Terintegrasi 2019.Bogor.UIKA Press.

Profil Desa Babakan Sadeng (2019). Profil Desa Babakan Sadeng.

Riswan, R., H. Sunoko dan A. Hadiyarto. (2011). Pengelolaan Sampah Rumah Tangga di Kecamatan Daha Selatan. Universitas Diponegoro.

Sahil, Jailan. Fachtur Rohman dkk. (2016). Sistem Pengelolaan dan Upaya Penanggulangan Sampah di
Kelurahan Dufa-Dufa Kota Ternate. Universitas Khairun.

Sari, Nilam. (2016). Analisis Pengelolaan Sampah Padat di Kecamatan Banuhampu Kabupaten Agam. Universitas Andalas.

Sulistiyorini, Rahmawati Nur, R. Saprudin Darwis dan A. Surya Gutama. (2015). Partisipasi Masyarakat Dalam Pengelolaan Sampah di Lingkungan Margaluyu Kelurahan Cicurug. Universitas Padjadjaran.

http://pkm.uikabogor.ac.id/index.php/ABDIDOS/iss ue/archive

http://pkm.uikabogor.ac.id/index.php/pkm-p 